\title{
Research on the Construction of Innovation and Entrepreneurship Education Ecology Circle of Local Applied University Students-The Space of Creation Perspective
}

\author{
ZHOU Zonghui \\ Changshu Institute of Technology, School of Economics and Management, Changshu, Jiangsu \\ 215500, China
}

email: 59238433@qq.com

\begin{abstract}
Keywords: innovation and entrepreneurship education, education ecosystem, the space of creation.
\end{abstract}

\begin{abstract}
With the development of China's economy and the vigorous development of various industries, innovation and entrepreneurship has become a national policy, so universities and colleges have also become an important position to encourage young people to start their own businesses, and innovation and entrepreneurship also need new forces to complete them. This can also promote the development of various industries in China. Therefore, in the current era of rapid economic development, encouraging college students to start their own business has played a crucial role in the development of various industries in our country. Moreover, college students, as the most important talents in the new century, encourage college students to innovate and start their own businesses for the future development of college students also has important significance. Taking the public creation space as an example, this paper analyzes the research on the educational ecosystem of innovation and entrepreneurship of college students in local application-oriented universities, and according to the development of innovation and entrepreneurship of college students, points out how to encourage college students to innovate and start their own businesses. It plays an important role in encouraging college students to innovate and start their own business.
\end{abstract}

\section{Introduction}

In the process of China's economic development, encouraging college students to innovate and start an enterprise plays an important role in the development of China's new industry. Since Premier Li Keqiang proposed "mass entrepreneurship and innovation" in 2015, more and more people have invested in the ranks of innovation and entrepreneurship. As a development platform for new innovative entrepreneurship proposed in the new era, the space of creation has played an important role in encouraging students to innovate and start their own businesses. The development of the space of creation needs to give full play to the social forces, and distribute more information about innovation and entrepreneurship to this platform, effectively utilizing the emerging technologies of China's independent innovation display areas, national high-tech zones, new application innovation parks, and technology enterprises. Develop favorable conditions for laboratories, universities and research institutes, and publish the latest innovation and entrepreneurial information on the space of the creation, and strive to play its due role to realize the combination of innovation and entrepreneurship, online and offline. The integration of innovation, innovation research and corporate investment provides entrepreneurs with a good working space and cyberspace and resource sharing space, enabling entrepreneurs to effectively improve the use of information and related resources, and provide effective information for innovative entrepreneurs.

\section{Overview of related theory}

\subsection{The meaning of the space of creation}

The space of creation is the innovative development platform. The "public" is the main body, referring to the innovative entrepreneurs. The "creation" is the content, referring to the innovation and entrepreneurship work; the "space" is the carrier, providing effective innovation and 
entrepreneurial information for the innovative entrepreneurs. . It is an inevitable trend of user innovation, open innovation, collaborative innovation and mass innovation in line with China's scientific and technological development. At the same time, the space of creation can also grasp the opportunities of global innovation and entrepreneurship, and use the deep development of the Internet and its applications to complete the right. The transmission of information, in line with the characteristics and needs of China's current innovation and entrepreneurship, can provide the most comprehensive information for innovative entrepreneurs, and build low-cost, convenient, and all-factors for innovation and entrepreneurship through market-oriented mechanisms, specialized services, and capitalization. It is open and open, and it has reached the problems of funds and channels that people have emerged in the early stage of the venture, and can be accepted by more innovative entrepreneurs.

\subsection{The role of the space of creation}

First of all, as already mentioned in the meaning of the space of creation, the creative space is a platform for information about innovation and entrepreneurship. Its role is to provide people with the latest innovation and entrepreneurial information in the process of innovation and entrepreneurship. Information to understand the level of innovation and entrepreneurship in the world, the use of people's understanding of their ability to innovate and create, has an important role in the development of entrepreneurial people. At the same time, the space of creation can also train the people who want to start a business to innovate and innovate, and improve the rate of innovation and entrepreneurship in China. The creation of the space for the creation of China is of great significance for China to encourage the people to innovate and innovate, to cultivate various innovative talents and innovative teams including college students, to drive the development of China's overall innovation and entrepreneurship, and to create a new "engine" for economic development.

\section{Selection of related factors and model construction}

Since its introduction, the space of creation has not only provided the world's advanced information for China's innovation and entrepreneurship, but also cultivated more and more innovative and entrepreneurial talents for China. At the same time, China has also begun to encourage college students and encourage college students to carry out Innovative entrepreneurship, which can not only input fresh blood to China's innovation and entrepreneurship, but also strengthen people's understanding of innovation and entrepreneurship, is of great significance to China's innovation and entrepreneurship development. In the process of education about innovation and entrepreneurship, the selection of relevant factors and the construction of models play an important role in the educational process. The following is a brief introduction to the selection of relevant factors and model construction when China uses the creative space to carry out innovation and entrepreneurship education.

\subsection{Selection of educational factors}

In the process of selecting relevant factors of education, it is necessary to analyze the brief development direction of the novice college students who are educated and innovated, and clearly define the future entrepreneurial goals of college students who accept innovation and entrepreneurship education, and carry out education around their goals.

First of all, the choice of education-related factors needs to be selected according to the future direction of the undergraduates who are educated, and the educational factors related to the future development direction of the innovative and entrepreneurial students are selected, and the teaching of various knowledge and information in this aspect is required. More comprehensive, it should be taught that college students should understand and learn the innovative and entrepreneurial knowledge. The specific educational content is simply the understanding of the market, the ability and funding of the team, and the understanding of advanced science and technology. Second, the choice of educational factors also needs to be based on the degree of understanding of knowledge and the difficulty of knowledge for beginners in innovation and entrepreneurship. In the process of 
education, if the content of education is too difficult, it will make the beginners of innovation and entrepreneurship suffer a greater psychological blow. They feel that innovation and entrepreneurship are too difficult and they have the idea of giving up. If the teaching content is too simple, beginners can't Good to learn from teaching about the real knowledge of innovation and entrepreneurship. Therefore, in the process of selecting relevant factors of education, we must grasp the understanding of college students on innovation and entrepreneurship and the direction they want to develop in the future, so as to make scientific and reasonable choice of education related factors.

As a fresh blood in the development process of innovation and entrepreneurship in China, college students can strengthen the innovation and entrepreneurship education of college students, which will help college students to form a sense of innovation and entrepreneurship. They can use this knowledge to complete and realize their dream of innovation and entrepreneurship in the future development.

\subsection{Structural Equation Module}

Because the space of creation serves as an information providing platform and education platform for online innovation and entrepreneurship, it also plays an important role in the selection of structural equation modules. The choice of structural equation modules can help the construction of models in innovation and entrepreneurship education, and can significantly improve China. The quality and efficiency of innovative entrepreneurship education. The structural equation module can be used to analyze multiple files using a single data file, and can also be used for sequential results and proportional and non-proportional assumptions. It is important for model building such as risk assumptions in the process of innovation and entrepreneurship education.

The structural equation module is a very good method in social science research. It has matured as early as the 1980s, but at that time, Chinese enterprises did not use this total evaluation method, so they understood the structural equation module in China. Not many people. In the social sciences and economics, markets, management and other research fields, sometimes it is necessary to deal with the relationship of multiple reasons, multiple results, or encounter variables that are not directly observable, that is, potential variables in economic development, generally not in Found in economic development, these are problems that traditional statistical methods cannot solve very well. Since the 1980s, the structural equation module has developed rapidly, making up for the shortcomings of traditional statistical methods and becoming an important tool for multivariate data analysis.

In the process of educating college students about innovation and entrepreneurship, the study of their team's ability and asset analysis and financial risk analysis is one of the most important innovations and entrepreneurial knowledge. Teachers need to use risk estimation method to educate new students such as college students. . Before the popular space was popularized, the teacher only relied on the explanation to complete the explanation of this time. This explanation method has certain limitations, which makes it difficult for students to understand. However, after the creation of space was popularized in the education of innovation and entrepreneurship, this problem was solved very well. The use of structural equations module solves the teaching problems existing in the analysis of diversification factors in the process of innovation and entrepreneurship in China. The structural equation module can simultaneously consider and deal with the characteristics of multiple dependent variables to make assumptions about the results. In the analysis process of the innovative entrepreneurs' own team and property, even if multiple dependent variables are displayed in the chart of statistical results, in the process of analyzing and modeling, each dependent variable is still calculated one by one to reflect The overall result. Therefore, in the process of structural equation modeling, it seems that multiple dependent variables are considered at the same time, but when calculating the influence or relationship of property risk values, it is still using a variable for analysis and modeling, but the estimation direction is different.

\section{Empirical analysis}

In the process of development, the space of creation has played an important role in the 
development of innovation and entrepreneurship in China. And it plays an important role in the actual process of innovation and entrepreneurship education. The following is an analysis of the practical application of the creation space.

\subsection{Descriptive statistics of sample data}

Descriptive statistics of sample data are statistical methods used to summarize and express the overall state of things and the associations and generic relationships between things. Through statistical processing, several statistical values can be used succinctly to represent a set of data centralized and discrete. In the process of using the creation space, the descriptive processing of sample data provides important research ideas for the development of innovation and entrepreneurship in China, and provides important help for the development of innovation and entrepreneurship in China. It is important for the development of innovation and entrepreneurship in China. effect.

\subsection{Reliability analysis}

Reliability has an important role to play for innovative entrepreneurs. The reliability of innovative entrepreneurs is high enough to have an important role in promoting the progress of innovation and entrepreneurship. Reliability is also the reliability often mentioned in daily life. It refers to the degree of consistency of results obtained by repeating measurements on the same object in the same way. Reliability indicators are mostly expressed by correlation coefficients, which can be roughly divided into three categories: stability coefficient, which refers to consistency across time; equivalent coefficient, which refers to consistency across forms; internal consistency coefficient, refers to cross Project consistency.

In the process of innovation and entrepreneurship in China, reliability is especially important for newcomers who are just involved in innovation and entrepreneurship. First of all, only in the process of innovation and entrepreneurship to ensure good faith, can college students and other first-time entrepreneurs start the next step of innovation and entrepreneurship, and in the early stage of the team's innovation and entrepreneurship can be completed with good faith and other The cooperation of large enterprises promotes the development of innovative and entrepreneurial teams, and the reliability can always maintain a normal state of enthusiasm for the innovation and entrepreneurship of team members.

\subsection{Model Analysis}

Model analysis is to use the construction model and other methods to simplify the analysis process and improve the efficiency of the analysis. At the same time, the model analysis is also a description of objective things or phenomena. A model is an abstract, objective thing or phenomenon of a research object, and it is a multi-factor complex. In the process of model construction, there are interdependent and mutually constrained relationships among various factors, usually complex nonlinear relationships.

Using model analysis, through the construction of the model, it is possible to simply analyze the property risk problem in the market in the process of using the creative space to carry out innovation and entrepreneurship. Model analysis is widely used in the creation of space, which requires teachers to use risk estimation to educate novices and other newcomers. Before the popular space was popularized, the teacher only relied on the explanation to complete the explanation of this time. This explanation method has certain limitations, which makes it difficult for students to understand. However, after the creation of space was popularized in the education of innovation and entrepreneurship, this problem was solved very well. The use of structural equations module solves the teaching problems existing in the analysis of diversification factors in the process of innovation and entrepreneurship in China. The structural equation module can simultaneously consider and deal with the characteristics of multiple dependent variables to make assumptions about the results.

\section{Conclusions and recommendations}

Through the analysis of the development process of the innovation and entrepreneurship and the 
application of the educational process, we can draw the conclusion that the space is in the process of innovation and entrepreneurship development in China. The following analysis analyzes the conclusions reached by the space of creation in the current utilization process in China, and proposes corresponding suggestions.

\subsection{Research conclusions}

As a development platform for new innovative entrepreneurship proposed in the new era, the space of creation has played an important role in encouraging students to innovate and start their own businesses. According to the conclusions drawn from the research of the space of creation, the development of the space of creation needs to give full play to the social forces, and distribute more information about innovation and entrepreneurship to this platform, effectively utilizing China's independent innovation display area and national high-tech. Districts, new application innovation parks, emerging technology development laboratories for science and technology enterprises, universities and research institutes and other places have the conditions to publish the latest innovation and entrepreneurial information on the space of the creation, and strive to play its due role. Therefore, it is important to make rational use of the space of creation and to play an important role in the education and publicity of innovation and entrepreneurship.

\subsection{Application-oriented college implementation path}

Nowadays, China has shifted the development of innovation and entrepreneurship to the innovation and entrepreneurship education of college students. Since college students are technical talents urgently needed in China, in the process of innovation and entrepreneurship development in China, improving the education of college students' innovation and entrepreneurship plays an important role in the injection of fresh blood of innovation and entrepreneurship in China.

\subsection{Government support implementation path}

Since Premier Li Keqiang proposed a new era of "mass entrepreneurship and innovation" in 2015, the government has greatly encouraged people to join the ranks of innovation and entrepreneurship, and in the process of people's innovation and entrepreneurship, the government has put forward Degree of economic support. First of all, the government has introduced a special channel for providing college students with interest-free loans in the process of college students' entrepreneurship, and solved the problem of the start-up funds for college students in innovation and entrepreneurship. In addition, the government also provides special development channels for innovative entrepreneurs. Provide free information on the world's cutting-edge innovation and entrepreneurship.

\subsection{School-enterprise cooperation implementation path}

Campus and business cooperation has also become an important means for encouraging college students to start their own businesses. Some large enterprises will enter colleges and universities to complete the recruitment of talents for enterprises. At the same time, they will also give college students some opportunities for innovation and entrepreneurship, or provide financial assistance to enable university students to solve external factors more easily in the process of innovation and entrepreneurship. Impact, fast startup.

\section{Conclusion}

The space created by the space of creation has an important significance in the development of innovation and entrepreneurship in China. First of all, the space of creation is a platform for information about innovation and entrepreneurship. Its role is to provide people with the latest innovation and entrepreneurial information in the process of innovation and entrepreneurship. Through this information, we can understand the level of innovation and entrepreneurship in the world. There is an understanding of people's ability to innovate and innovate, which plays an important role in the development of entrepreneurial people. At the same time, the space of creation can also train the people who want to start a business to innovate and innovate, and improve the rate 
of innovation and entrepreneurship in China. In today's era of rapid economic development, encouraging college students to start a business has played a vital role in the development of various industries in China. This paper analyzes the educational ecological circle of college students' innovation and entrepreneurship in the field of applied colleges and universities, and analyzes the development of college students' innovation and entrepreneurship according to the creation space, and points out how to encourage college students to innovate and start their own business. College students' innovation and entrepreneurship play an important role. It is the responsibility of everyone in China to actively develop the practicality of the space created by the people and improve the level of innovation and entrepreneurship in China.

\section{Acknowledgment}

Jiangsu University Philosophy and Social Science Research Fund-funded Project "Research on the Construction of Innovation and Entrepreneurship Education Eco-sphere in Applied Universities_-Based on the Perspective of the space of creation Development" (2018SJA1385 and Changshu Institute of Technology Student Work Project "Application-oriented University Innovation and Entrepreneurship Education Eco-sphere Construction Research" (QS1607

\section{References}

[1] Harry Lewis. The loss of soul excellence [M]. Hou Dingkai, translated. Shanghai: East China Normal University Press, pp. 8-15, 2007

[2] Lin Chongde, et al. Research on innovative talents and educational innovation [M]. Beijing: Economic Science Press, pp. 25-29, 2009.

[3] Li Shuangjin, Zheng Yujia. The Choice of Organization Mode of College Creative Space_-Based on the Perspective of Control Rights[J]. Shanghai Economic Research, vol. 8, pp. 38-44,2018.

[4] Lu Qiuping. Research on the "Three-in-One" Entrepreneurship Education Model in Colleges and Universities —-Based on the development of Zhejiang "the space of creation" [J]. Special Zone Management, vol. 5, pp. 54-56,2018.

[5] Hu Xueyan; Li Wenzhao. Research on the Different Development Path of "the space of creation" in Nanjing__Based on the Perspective of Maker's Demand. Item Quality; Economic Research Guide, vol. 25, pp. 130-131,2018.

[6] Robert K Yin, Zhou Haitao, Li Yongxian, et al. Case Study: Design and Method [M]. Chongqing: Chongqing University Press, pp. 45-55,2009.

[7] Chen Xiaoping. Organizational Management and Empirical Research Methods [M]. Beijing: Peking University Press, pp. 50-55,2008.

[8] Duan Hao, Chen Ying. China's maker space map and development model [J]. China Industrial Review, vol. 7, pp. 58-65,2015.

[9] Li Shuangshou, Yang Jianxin, Wang Deyu, Fu Zhiyong, Gu Xueyu. College practice space construction practice [J]. Modern educational technology. vol. 5, pp. 5-11,2015.

[10] Wang Zhanren, Liu Haibin, Li Zhongyuan. The role of Zhongchuang Space in the innovation and entrepreneurship education in colleges and universities [J]. Ideological theory education. vol. 2, pp. 85-91,2016.

[11] Yang Xiaohui. Research on Entrepreneurship Education and Innovative Talents Cultivation in Colleges and Universities in China[J]. China Higher Education Research, vol. 1, pp. 39-44,2015. 